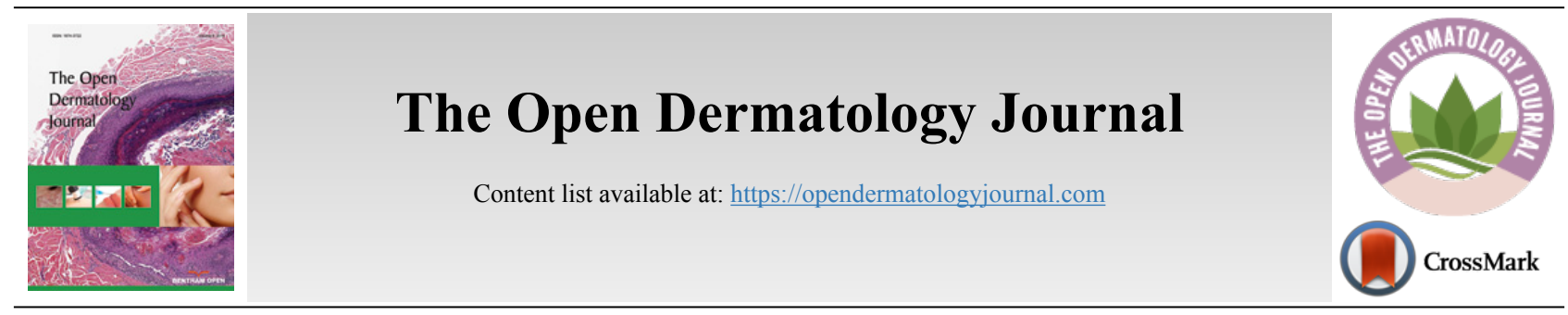

RESEARCH ARTICLE

\title{
Clinical Aspects of Atopic Dermatitis of Children in Brazzaville, Congo.
}

\author{
Edith Sophie Bayonne-Kombo ${ }^{1,3, *(\mathbb{C})}$, Hébert Loubove ${ }^{2}(\mathrm{D})$ Yannichka Gloria Voumbo Mavoungou $^{3}$ and Alphonse \\ Gathsé ${ }^{1}$
}

${ }^{I}$ Department of Faculty Health Sciences, Marien Ngouabi University, Brazzaville, Congo

${ }^{2}$ Department of Pediatry, Talangaï Reference Hospital, Brazzaville, Congo

${ }^{3}$ Department of Dermatology and Infectious Diseases, Talangaï Reference Hospital, Brazzaville, Congo

\begin{abstract}
:
Background:

Atopic dermatitis is a chronic inflammatory dermatosis for which racial specificities have been reported.

Objective:

To describe the clinical aspects of atopic dermatitis on children.

Methods:

Descriptive cross-sectional study in one public hospital and one private hospital in Brazzaville, Congo, for three years. Children under the age of 16, consulted for atopic dermatitis were included. Demographic and clinical data were collected. Atopic dermatitis was defined according to the criteria of the United Kingdom Working Party and its severity appreciated by SCORAD. The data was processed by EpiInfo 7® software.

Results:

Seventy-five children were included. They were 49 girls ( $65.33 \%$ ) and 26 boys (34.67\%), mean age 4.3 years [ 9 months- 12 years]. Personal atopic history was found in $46.67 \%$ of cases and family atopic history in $61.33 \%$ of cases. Initial symptoms of atopic dermatitis had occurred before 2 years of age for 65 children $(86.67 \%)$. The average consultation time was 33.4 months. In infancy, erythematous vesicular or oozing plaques were observed in $68.18 \%$ of cases and scaly erythematous plaques on folds in $50 \%$ of cases. In childhood, scaly erythematous plaques were observed in $84.90 \%$ of cases and lichenified eczema in $10.67 \%$ of cases. Xerosis was noted in $89.33 \%$ of all cases. Secondary infection was seen in $33.33 \%$ of cases. Twenty-five cases $(33.33 \%)$ were severe.

Conclusion:

This study reveals a delayed diagnosis of atopic dermatitis, unusual clinical features and the importance of secondary infection. Information for families and clinicians should be considered to improve the earliness of the diagnosis.
\end{abstract}

Keywords: Atopic dermatitis, Ezcema, Inflammatory dermatosis, Chronic disease, Children, Congo.

\begin{tabular}{l|l|l|r}
\hline Article History & Received: September 05, 2019 & Revised: November 19, 2019 & Accepted: December 06, 2019
\end{tabular}

\section{INTRODUCTION}

Atopic Dermatitis (AD) is a chronic pruriginous inflammatory dermatosis associated with atopy. It mostly begins during childhood, but can also begin in adulthood. The global prevalence of $\mathrm{AD}$ in children is $7.89 \%$, with diversity by geographic area [1]. The disease has a heavy economic burden for the affected households, particularly in countries with low health

\footnotetext{
* Address correspondence to this author at the Department of Faculty Health Sciences, Marien Ngouabi University, PO Box 13423, Brazzaville, Congo; Tel: (+242) 055785562; E-mail: sophiekbb@outlook.com
}

coverage. It also has a significant impact on the quality of life of children and families $[2,3]$.

The diagnosis of AD is based on clinical criteria. Clinical aspects have been widely described in the Caucasian population $[4,5]$, while on black skin, they remain insufficiently documented. As a result, racial and ethnic specificities regarding the clinical manifestations of $\mathrm{AD}$ are increasingly reported $[6,7]$.

In order to help define the patterns of atopic dermatitis in 
the black-skinned subject, the objective of this study was to describe the clinical aspects of atopic dermatitis on children in Brazzaville, Congo.

\section{PATIENTS AND METHODS}

This was a bicentric, descriptive cross-sectional study conducted from January 2016 to December 2018 in Brazzaville, Congo in two health facilities: Talangai Reference Hospital in Dermatology and infectious diseases Department and Cogemo private Hospital.

Children aged from 1 month to 15 years, consulted for atopic dermatitis in outpatient dermatology, were included. Children already treated for atopic dermatitis were not included. The diagnosis of atopic dermatitis was based on the criteria of the United Kindom Working Party [8].

The sampling was exhaustive in accordance with the inclusion criteria. The data were collected on a pre-established form during consultation through interrogation and physical examination. The variables studied were demographic data (age, sex, place of residence), history taken (personal and family history of atopic disease, age at the onset of symptoms, time interval and medication received before the consultation) and examination (type of dermatological lesions, topography, complications, degree of severity).

Among the complications, the bacterial secondary infection was defined by the presence of pus or honey-colored crusts on the lesions of atopic dermatitis and viral infection was defined by the presence of punched-out erosions or vesicles with or without fever $[9,10]$. The degree of severity was appreciated by the SCORAD index $[11,12]$. The AD has a score of 15 for mild cases, a score between $15-40$ for moderate cases and above 40 for severe cases.

The data were processed using Epi Info $7 \circledR$ software. The qualitative variables were expressed in number and percentage. Quantitative variables were expressed on mean with extreme values.

\section{RESULTS}

\subsection{Socio-demographic Characteristics of the Study Population}

Seventy-five children were included in the study. They were 49 girls $(65.33 \%)$ and 26 boys $(34.67 \%)$. The mean age was 4.3 years ( 9 months-12 years). Twenty-two children $(29.33 \%)$ were under 2 years of age and 53 children $(70.67 \%)$ were 2 years or older. Within all children, 34 (45.33\%) were from a public hospital and $41(54.67 \%)$ from a private hospital. The place of residence was urban for $74(98.67 \%)$ children and rural for one child.

\subsection{Clinical Aspects of Atopic Dermatitis}

A personal history of atopy was noted in 35 cases (46.67\%). These were allergic rhinitis in 20 cases $(26.67 \%)$, asthma in 16 cases $(21.33 \%)$ and allergic conjunctivitis in 8 cases $(10.67 \%)$. A family history of atopy was found in 46 cases $(61.33 \%)$.
Initial symptoms of AD had occurred before 2 years of age in 65 cases $(86.67 \%)$, and after 2 years of age in 10 cases $(13.33 \%)$. The average duration of the disease progression at the time of the consultation was 33.4 months $(0-120)$. Prior to consultation, oral use of antibiotics was noted in 24 cases $(32,00 \%)$. Local application of antibiotics, corticosteroids and vaseline was noted in 26 (34.67\%), $30(40.00 \%)$ and 23 $(30.67 \%)$ cases, respectively. Five children had received traditional treatment.

Pruritus was found in all children. Among the classic lesions of $\mathrm{AD}$ (eczema), erythematous vesicular or oozing plaques were found in 21 of 75 cases (28\%), scaly erythematous plaques (Fig. 1) were found in 56 cases (74.67\%) and poorly-demarcated papules (Fig. 2) were noted in 29 cases $(68.67 \%)$.

The distribution of eczema lesions by age group is presented in Table $\mathbf{1}$.

For atypical forms, the lichenoid atopic dermatitis (Fig. 3) was observed in 8 cases $(10.67 \%)$, nummular-type atopic dermatitis in 7 cases $(9.33 \%)$ and follicular atopic dermatitis in 4 cases $(5.33 \%)$.

The various morphologic pattern might exist in the same child. The location of eczema lesions according to the clinical type and the age is presented in Table $\mathbf{2}$. The other clinical manifestations observed in children with atopic dermatitis, are reported in Table 3 .

The degree of severity of atopic dermatitis was moderate in 50 cases $(66.67 \%)$ and severe in 25 cases $(33.33 \%)$.

Bacterial secondary infection was noted in 25 cases (33.33\%) (Fig. 4).

\section{DISCUSSION}

The objective of our study was to describe the clinical aspects of atopic dermatitis in children, through a pediatric population consulted in outpatient dermatology.

The sample, composed mainly of children living in urban areas, is a limitation of this study. The diagnosis of $\mathrm{AD}$ was based on the United Kindom Working Party criteria because of its practical validity and high sensitivity [13 - 15]. These criteria are widely used for epidemiological and clinical studies of children [4].

Eczema is a cutaneous manifestation of atopy which is defined as a hereditary predisposition to develop IGE-mediated reactions to common environmental antigens [16]. A personal history of atopy was found in $46.67 \%$ of the children in our study and family history in $61.33 \%$ of cases. The frequency of atopy history varies depending on the studies. Out of a hospital study of 70 children in Côte d'Ivoire, Ahogo reports the existence of personal atopy in $57.24 \%$ of cases and a family history of atopy in $67.2 \%$ of cases [15]. In Israel, Rottem found a family history of atopy in $41.3 \%$ of cases in a hospital study [16]. In a community study in India, Narayan noted lower rates, $18.8 \%$ for personal atopy history, and $52.73 \%$ for family history [17]. 


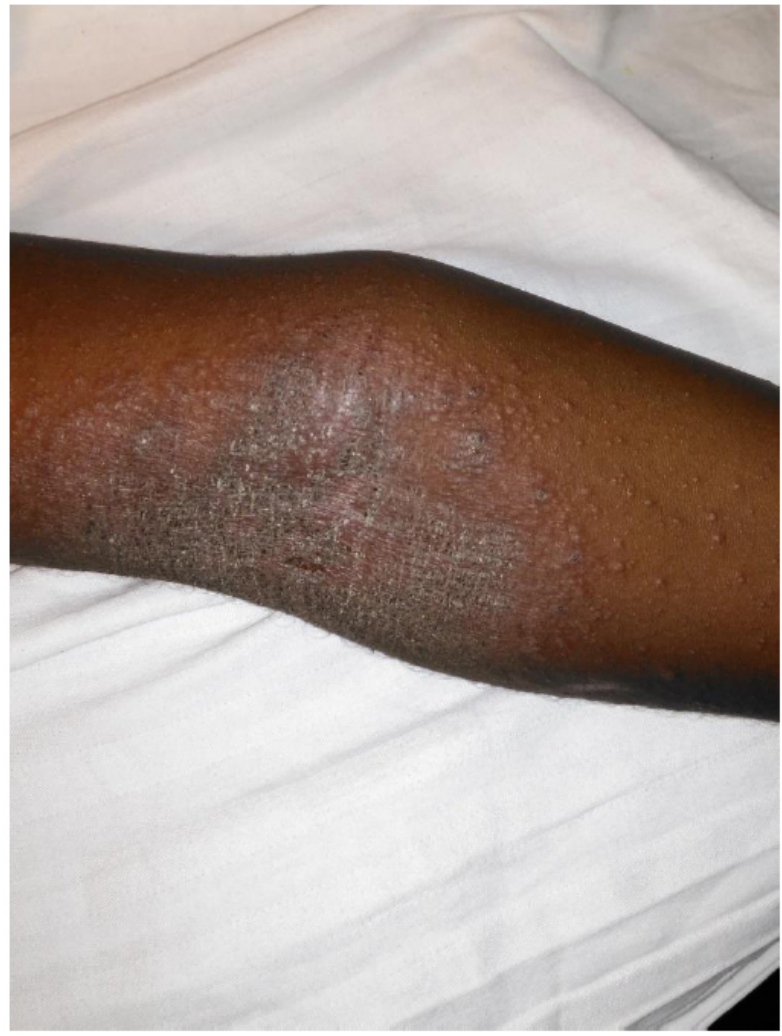

Fig. (1). Scaly erythematous plaque on anterocubital fold.

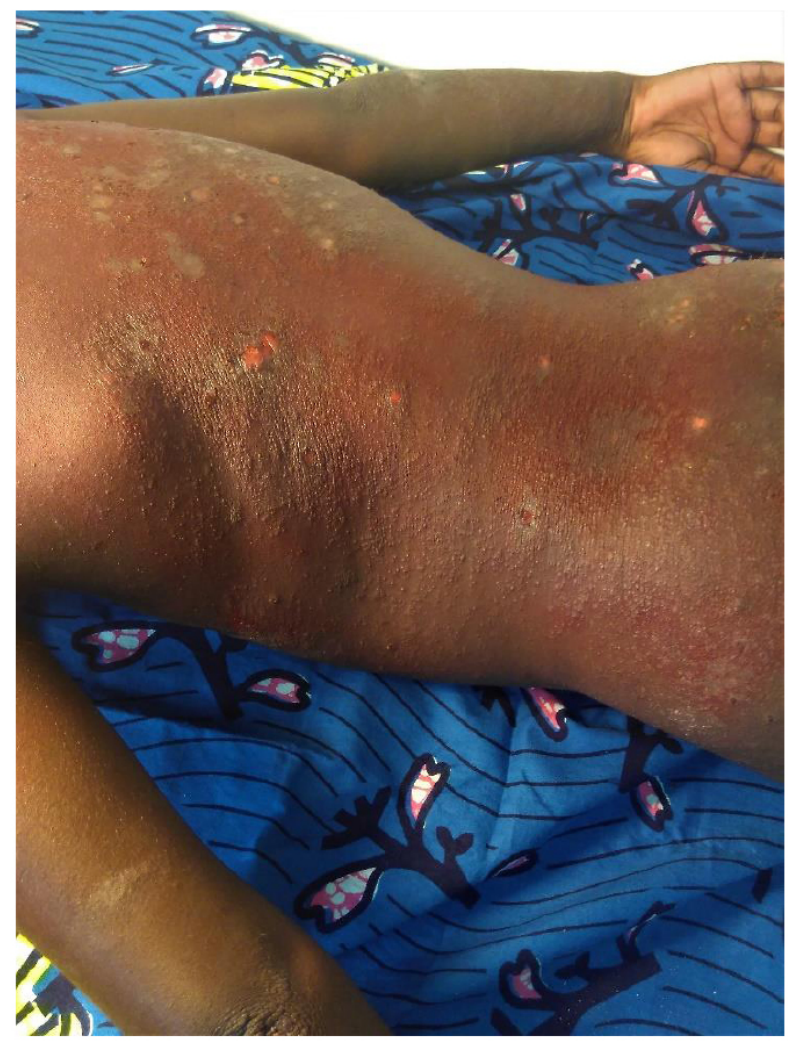

Fig. (2). Diffuse poorly-demarcated erythematous papules with secondary infection. 


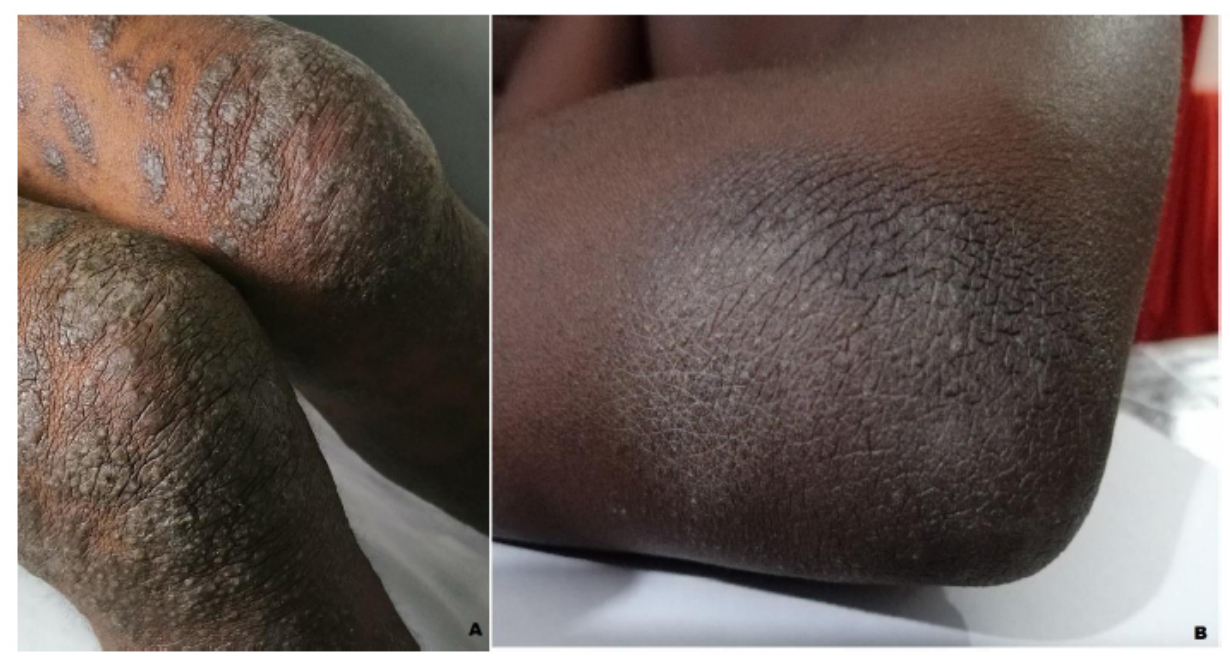

Fig. (3). (A)-Lichenoid atopic dermatitis is 5 years-old child. (B) Lichenoid plaque of extensor side of elbow in 11 years-old child with atopic dermatitis.

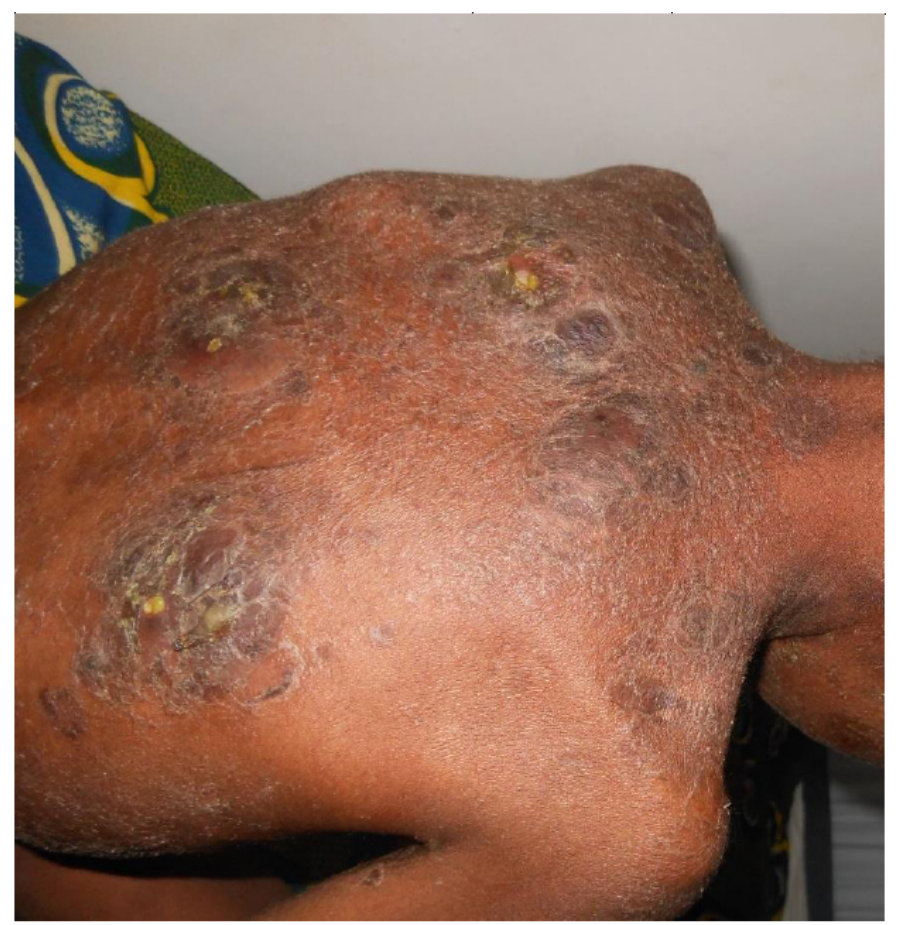

Fig. (4). Bacterial secondary infection and xerosis in a child with atopic dermatitis.

Table 1. Clinical characteristics of eczema by age group.

\begin{tabular}{|c|c|c|c|c|}
\hline \multirow{2}{*}{ Clinical Characteristics of Eczema } & \multicolumn{2}{|c|}{$<\mathbf{2}$ years-old (infancy) } & \multicolumn{2}{|c|}{$\begin{array}{c}\mathbf{2} \text { years-old (childhood) } \\
\mathbf{N}=\mathbf{5 3}\end{array}$} \\
\cline { 2 - 5 } & $\mathbf{n}$ & $\mathbf{\%}$ & $\mathbf{n}$ & $\mathbf{\%}$ \\
\hline Erythematous, vesicular or oozing plaques & 15 & 68.18 & 6 & 11.32 \\
\hline Poorly-demarcated erythematous papules & 16 & 72.73 & 13 & 24.52 \\
\hline Scaly erythematous plaques & 11 & 50.00 & 45 & 84.90 \\
\hline
\end{tabular}


Table 2. Distribution of dermatological lesions among 75 children with atopic dermatitis according the age group.

\begin{tabular}{|c|c|c|c|}
\hline Dermatological Lesions & Topography & $\begin{array}{c}<2 \text { years-old } N=22 \\
\text { Number }(\%)\end{array}$ & $\begin{array}{c}\geq 2 \text { years-old } \mathrm{N}=53 \\
\text { Number }(\%)\end{array}$ \\
\hline \multirow[t]{4}{*}{ Erythematous vesicular or oozing lesions } & Checks & $13(59.09)$ & $4(7.54)$ \\
\hline & Scalp & $1(4.54)$ & - \\
\hline & Neck & $1(4.54)$ & - \\
\hline & Folds & - & $2(3.77)$ \\
\hline \multirow[t]{7}{*}{ Scaly erythematous plaques } & Large folds* & $11(50.00)$ & $38(71.69)$ \\
\hline & Trunk & - & $14(26.41)$ \\
\hline & Diffuse & - & $4(7.54)$ \\
\hline & Face & - & $4(7.54)$ \\
\hline & Neck & - & $8(15.09)$ \\
\hline & Thighs & - & $4(7.54)$ \\
\hline & Other locations & - & $15(28.30)$ \\
\hline \multirow[t]{4}{*}{ Pooly-demarcated erythematous papules } & Face & $7(31.81)$ & $7(13.20)$ \\
\hline & Trunk & $7(31.81)$ & $3(5.66)$ \\
\hline & Diffuse & $4(18.18)$ & $2(3.77)$ \\
\hline & Other locations & - & $4(7.54)$ \\
\hline \multirow[b]{2}{*}{ Lichenified plaques } & Extensor side of limbs & - & $7(13.20)$ \\
\hline & Large folds* & - & $1(1.88)$ \\
\hline \multirow[b]{2}{*}{ Nummular patch } & Trunk & - & $5(9.43)$ \\
\hline & Legs & - & $2(3.37)$ \\
\hline Follicular eczema & Trunk & - & $4(7.54)$ \\
\hline
\end{tabular}

*antecubital and popliteal fossae.

Table 3. Others clinical features seen in $\mathbf{7 5}$ children with atopic dermatitis.

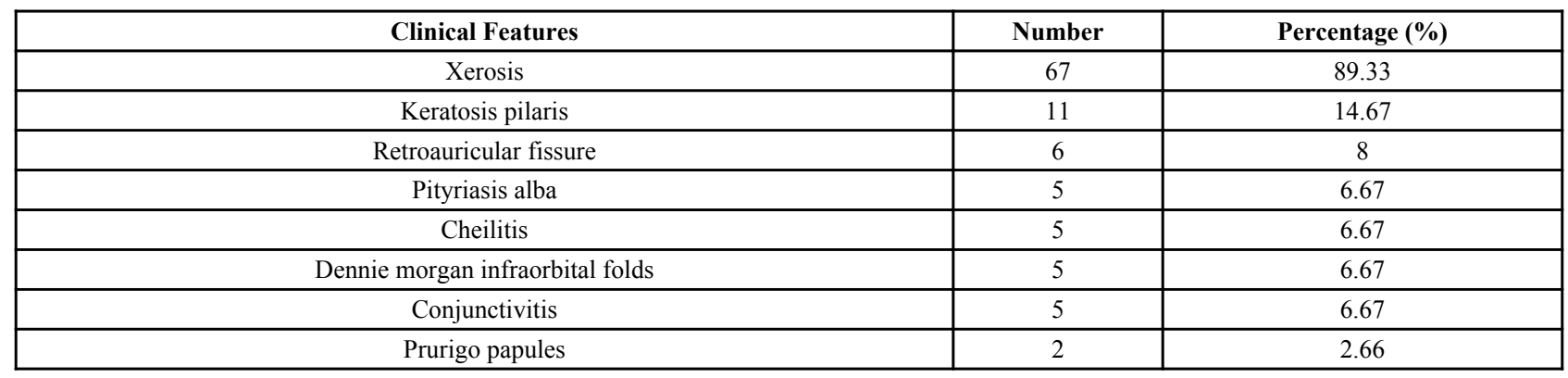

Among the symptoms of atopy, the frequency of asthma in our study $(21.33 \%)$ is close to Ahogo in Côte d'Ivoire (25.7\%) [15], whereas a population study in Togo by Técléssou revealed asthma frequency of $12.08 \%$ [18]. The study by Técléssou also found an association between the personal history of asthma and the development of atopic dermatitis [18]. Different studies show that history of atopy is a diagnostic element whose association with atopic dermatitis varies according to studies: the history of atopy is generally lower in population studies than in hospital studies [19].

In spite of the age of onset of $\mathrm{AD}$ was before 2 years for $86.67 \%$ of the children in our study, access to care was late and the average consultation time was 33.4 months. Also, to help to treat symptoms, $32.00 \%$ of cases used oral antibiotics and 5 children resorted to inappropriate use of traditional medicine. Traditional treatments used on AD children were plant extracts or traditional oils. These practices have not been effective for the symptoms.
There are two major periods in the clinical manifestations of atopic dermatitis: infancy and childhood. During infancy, $\mathrm{AD}$ presents classically by acute eczematous lesions characterized by erythematous, vesicular papules found on the face, sparing the nose, and on the extensor side of extremities [20 - 22]. Flexural areas may be involved, particularly the neck fold [23]. During childhood, the involvement of the face is less frequent and eczema has a chronic presentation characterized by scaly erythematous or lichenified plaques of the large flexion folds and neck [5, 24].

Our study confirms the predominance of acute lesions localized on the cheeks, the trunk or diffuse. It reveals, in infants, the early onset of chronic eczema lesions on the large flexion folds without involving the limb extension faces. In children, the lesions observed in our study are similar to the common description of AD. However, the appearance of erythema and lichenifiction on black skin can make diagnosis difficult. The erythema is gray on black skin and the color is 
close to lichenification. The acute and chronic character of eczema lesions are often only distinguished by the thickening of the skin during lichenification. Atypical forms of eczema, such as follicular, nummular and lichenoid forms are classified as atypical forms of $\mathrm{AD}[20]$. Among atypical forms of $\mathrm{AD}$, the lichenoid form was found in $10.67 \%$ of cases and the follicular form in $5.33 \%$ of cases. Lichenoid atopic dermatitis and follicular $\mathrm{AD}$ are more frequent variants of $\mathrm{AD}$ seen in African-American and Latino-Hispanic patients [4, 7, 20]. Nnoruka, in Nigerian patients with $\mathrm{AD}$, found a papular lichenoid lesion in 54\% of cases [25]. Ahogo in Côte d'Ivoire observed this clinical form in $7.1 \%$ of cases [15]. JulianGonzalez in Mexico reports a lichenoid AD frequency of 7\% [26]. A meta-analysis shows a high frequency of lichenoid forms in African countries, including Nigeria, Tunisie and South Africa [5]. Contrary to the usual localization, in our study, the lichenoid AD was located on the extensor side of the limbs or diffuse. Summey made the same finding on AfricanAmerican with AD [27]. The lichenoid form is different from lichenification secondary to old lesions. AD lichenoid occurs early as flat lichen lesions, pigmented and sometimes hypertrophic. It requires a good appreciation of all diagnostic criteria of AD.

Xerosis was seen in $89.33 \%$ children. A meta-analysis showed that xerosis was among the top 5 most commonly reported features of $\mathrm{AD}$ in all regions of the world except Southeast Asia [5]. This analysis shows in 3 African countries, namely Nigeria, Tunisia and South Africa, that xerosis is found on average in $65 \%$ of cases [5]. The decreased and changed lipid content of the skin is one of the contributing factors to xerosis. Also, patients with $\mathrm{AD}$ have an increase in transepidermal water loss, which reduces the water content of the skin [28]. In our study pityriasis alba was found in $6.67 \%$ of AD children. It looked like hypopigmented patches located on the face and trunk. This condition is usually found at school age. Some studies report that this condition is more common in black-skinned subjects, but in fact, the condition is equirevalent in all skin types, and just more apparent on the pigmented skin [29].

Among over the atopic stigmata, conjunctival disease, found in $6.67 \%$ of the children in this study, is lower than that seen by Carmi in France in $18 \%$ of cases [24]. In India, Kaujalgi [30] reports eye damage in $16 \%$ of cases and Sarkar [31] in $43 \%$ of cases.

In our study, $33.33 \%$ of cases of $\mathrm{AD}$ were complicated by a secondary bacterial infection. Ahogo in Côte d'Ivoire observed a lower frequency of $12.8 \%$ [15]. In the skin of patients with atopic dermatitis, malformation of the lipid layer, increased $\mathrm{pH}$, and elevated transepidermal water loss contribute to the colonization and proliferation of $S$. aureus $[32,33]$.

In our context, other factors can contribute to the development of secondary infections. Delayed access to care is usually compensated by adverse therapeutic practices such as the application of inappropriate substances, which can alter the skin microbiota and promote infections. The unsanitary environment can also contribute to the infection.

\section{CONCLUSION}

Our study shows the early onset of chronic eczema form on large folds in infants, the predominance of lichenoid atopic dermatitis on extensor sides of extremities in children, and the importance of secondary infection. These findings should be taken into account to improve the diagnosis of atopic dermatitis

\section{LIST OF ABBREVIATIONS}

\section{AD $=$ Atopic Dermatitis \\ SCORAD $=$ Scoring of Atopic Dermatitis \\ ETHICS APPROVAL AND CONSENT TO PARTI- CIPATE}

The Hospital Research Committee of Talangai Reference Hospital Brazzaville, Congo approved the study under the approval number 6947/MPPIFID /DGSSSa/DDSSSaB/DST/HRT).

\section{HUMAN AND ANIMAL RIGHTS}

No Animals were used in this research. All human research procedures were followed in accordance with the ethical standards of the committee responsible for human experimentation (institutional and national), and with the Helsinki Declaration of 1975, as revised in 2013.

\section{CONSENT FOR PUBLICATION}

Informed consent was priorily obtained from all the parents.

\section{FUNDING}

None.

\section{CONFLICT OF INTEREST}

The authors declare no conflict of interest, financial or otherwise.

\section{ACKNOWLEDGEMENTS}

Declared none.

\section{REFERENCES}

[1] Davies E, Rogers NK, Lloyd-Lavery A, Grindlay DJC, Thomas KS. What's new in atopic eczema? An analysis of systematic reviews published in 2015. Part 1: Epidemiology and methodology. Clin Exp Dermatol 2018; 43(4): 375-9.

[http://dx.doi.org/10.1111/ced.13377] [PMID: 29314180]

[2] Lewis-Jones S. Quality of life and childhood atopic dermatitis: The misery of living with childhood eczema. Int J Clin Pract 2006; 60(8): 984-92.

[http://dx.doi.org/10.1111/j.1742-1241.2006.01047.x] [PMID: 16893440]

[3] Pustišek N, Vurnek Živković M, Šitum M. Quality of life in families with children with atopic dermatitis. Pediatr Dermatol 2016; 33(1): 28-32.

[http://dx.doi.org/10.1111/pde.12698] [PMID: 26459969]

[4] Weidinger S, Novak N. Atopic dermatitis. Lancet 2016; 387(10023): 1109-22.

[http://dx.doi.org/10.1016/S0140-6736(15)00149-X] [PMID: 26377142]

[5] Yew YW, Thyssen JP, Silverberg JI. A systematic review and metaanalysis of the regional and age-related differences in atopic dermatitis clinical characteristics. J Am Acad Dermatol 2019; 80(2): 390-401. 
[http://dx.doi.org/10.1016/j.jaad.2018.09.035] [PMID: 30287309]

[6] Leung DYM. Atopic dermatitis: Age and race do matter! J Allergy Clin Immunol 2015; 136(5): 1265-7.

[http://dx.doi.org/10.1016/j.jaci.2015.09.011] [PMID: 26549637]

[7] Mei-Yen Yong A, Tay Y-K. Atopic dermatitis: Racial and ethnic differences. Dermatol Clin 2017; 35(3): 395-402.

[http://dx.doi.org/10.1016/j.det.2017.02.012] [PMID: 28577807]

[8] Williams HC, Burney PG, Hay RJ, et al. The U.K. Working Party's Diagnostic Criteria for Atopic Dermatitis. I. Derivation of a minimum set of discriminators for atopic dermatitis. Br J Dermatol 1994; 131(3): 383-96.

[http://dx.doi.org/10.1111/j.1365-2133.1994.tb08530.x] [PMID: 7918015]

[9] Tom WL, Eichenfield LF. Eczematous Disorders In Eichenfield LF, Ilona J. Frieden IJ, Erin F, Mathes EF, Zaenglein AL. Neonatal and Infant Dermatology. Third Edition Elsevier Saunders, London-New York, Oxford 2014; p. 216-232.

[10] Lyons JJ, Milner JD, Stone KD. Atopic dermatitis in children: Clinical features, pathophysiology, and treatment. Immunol Allergy Clin North Am 2015; 35(1): 161-83.

[http://dx.doi.org/10.1016/j.iac.2014.09.008] [PMID: 25459583]

[11] Kunz B, Oranje AP, Labrèze L, Stalder JF, Ring J, Taïeb A. Clinical validation and guidelines for the SCORAD index: Consensus report of the European Task Force on Atopic Dermatitis. Dermatology (Basel) 1997; 195(1): 10-9.

[http://dx.doi.org/10.1159/000245677] [PMID: 9267730]

[12] Williams HC. Diagnostic criteria for atopic dermatitis: Where do we go from here? Arch Dermatol 1999; 135(5): 583-6.

[http://dx.doi.org/10.1001/archderm.135.5.583] [PMID: 10328200]

[13] De Bruin-Weller. Knulst AC, Meijer Y, Bruinjnzeel-Koomen CAFM, Pasmans SGM. Evaluation of child with atopic dermatitis. Clin Exp Allergy 2012; (42): 352-62.

[14] Skaaby T, Husemoen LLN, Thuesen BH, Hammer-Helmich L, Linneberg A. Atopy and cause-specific mortality. Clin Exp Allergy 2014; 44(11): 1361-70

[http://dx.doi.org/10.1111/cea.12408] [PMID: 25220375]

[15] Ahogo KC, Kouassi YI, Gbery IP. AZagoh KR, Yeboua KI, Kouassi $\mathrm{KA}$ and $\mathrm{al}$. Atopic dermatitis in children: Epidemiologiac and clinicals aspects in Côte d'Ivoire. Our Dermatol Oneline 2017; 8(Suppl. 1): 25-7.

[http://dx.doi.org/10.7241/ourd.2017s.6]

[16] Rottem M, Darawsha J, Zarfin J. Atopic dermatits in infants and children in Israel: Clinical presentation, allergies and outcome. Isr Med Assoc J 2004; 6(4): 209-12.

[PMID: 15115258]

[17] Narayan V, Sarkar R, Barman KD, Prakash SK. Clinicoepidemiologic profile and the cutaneous and nasal colonization with methicillinresistant Staphylococcus aureus in children with atopic dermatitis from North India. Indian Dermatol Online J 2019; 10(4): 406-12.

[http://dx.doi.org/10.4103/idoj.IDOJ_359_18] [PMID: 31334059]

[18] Técléssou JN, Mouhari-Touré A, Akakpo S, et al. [Risk factors and allergic manifestations associated with atopic dermatitis in Lomé (Togo): A multicenter study of 476 children aged 0-15 years]. Med Sante Trop 2016; 26(1): 88-91.

[http://dx.doi.org/10.1684/mst.2016.0534] [PMID: 26986820]

[19] Flohr C, Johansson SG, Wahlgren CF, Williams H. How atopic is atopic dermatitis? J Allergy Clin Immunol 2004; 114(1): 150-8. [http://dx.doi.org/10.1016/j.jaci.2004.04.027] [PMID: 15241359]

[20] Silverberg NB. Typical and atypical clinical appearance of atopic dermatitis. Clin Dermatol 2017; 35(4): 354-9.

[http://dx.doi.org/10.1016/j.clindermatol.2017.03.007] [PMID: 28709565]

[21] Thestrup-Pedersen K. Clinical aspects of atopic dermatitis. Clin Exp Dermatol 2000; 25(7): 535-43.

[http://dx.doi.org/10.1046/j.1365-2230.2000.00696.x] [PMID: 11122225]

[22] Leung DYM, Eichenfield LF, Boguniewicz M. Atopic dermatitis (Atopic eczema).Fitzpatrick's Dermatology in General Medecine. New York: Mc-Graw Hill Medical 2012; pp. 165-82.

[23] Deleuran M, Vestergaard C. Clinical heterogeneity and differential diagnosis of atopic dermatitis. Br J Dermatol 2014; 170(Suppl. 1): 2-6. [http://dx.doi.org/10.1111/bjd.12933] [PMID: 24720512]

[24] Carmi E, Defossez-Tribout C, Ganry O, et al. Ocular complications of atopic dermatitis in children. Acta Derm Venereol 2006; 86(6): 515-7. [http://dx.doi.org/10.2340/00015555-0163] [PMID: 17106598]

[25] Nnoruka EN. Current epidemiology of atopic dermatitis in southeastern Nigeria. Int J Dermatol 2004; 43(10): 739-44.

[http://dx.doi.org/10.1111/j.1365-4632.2004.02360.x] [PMID: 15485531]

[26] Julián-Gónzalez RE, Orozco-Covarrubias L, Durán-McKinster C, Palacios-Lopez C, Ruiz-Maldonado R, Sáez-de-Ocariz M. Less common clinical manifestations of atopic dermatitis: Prevalence by age. Pediatr Dermatol 2012; 29(5): 580-3.

[http://dx.doi.org/10.1111/j.1525-1470.2012.01739.x] [PMID: 22469300]

[27] Summey BT, Bowen SE, Allen HB. Lichen planus-like atopic dermatitis: Expanding the differential diagnosis of spongiotic dermatitis. J Cutan Pathol 2008; 35(3): 311-4.

[http://dx.doi.org/10.1111/j.1600-0560.2007.00806.x]

[PMID: 18251746

[28] Thestrup-Pedersen K. Clinical aspects of atopic dermatitis. Clin Exp Dermatol 2000; 25(7): 535-43.

[http://dx.doi.org/10.1046/j.1365-2230.2000.00696.x] [PMID: 11122225]

[29] Lin RL, Janniger CK. Pityriasis alba. Cutis 2005; 76(1): 21-4. [PMID: 16144284]

[30] Kaujalgi R, Handa S, Jain A, Kanwar AJ. Ocular abnormalities in atopic dermatitis in Indian patients. Indian J Dermatol Venereol Leprol 2009; 75(2): 148-51.

[http://dx.doi.org/10.4103/0378-6323.48659] [PMID: 19293501]

[31] Sarkar R, Narang I. Atopic dermatitis in Indian children: The influence of lower socioeconomic status. Clin Dermatol 2018; 36(5): 585-94. [http://dx.doi.org/10.1016/j.clindermatol.2018.05.009] [PMID: 30217271]

[32] Abeck D, Mempel M. Staphylococcus aureus colonization in atopic dermatitis and its therapeutic implications. Br J Dermatol 1998; 139(Suppl. 53): 13-6. [http://dx.doi.org/10.1046/j.1365-2133.1998.1390s3013.x] [PMID: 9990408]

[33] Boguniewicz M, Leung DYM. Recent insights into atopic dermatitis and implications for management of infectious complications. J Allergy Clin Immunol 2010; 125(1): 4-13. [http://dx.doi.org/10.1016/j.jaci.2009.11.027] [PMID: 20109729] 